\title{
Pengembangan Prototipe Alat Bantu Latihan Reaksi Yang Mengunakan Sinyal Lampu Dan Bunyi Terhadap Kecepatan Lemparan Atas Softball
}

\section{Development Of A Reaction Exercise Training Prototype Using The Lamp And Sound Signal Against The Sheet Speed On The Softball}

Agus Arief Rahmat ${ }^{1}$, Aang Rohyana ${ }^{2}$

${ }^{1,2}$ Faculty Of Teacher Training and Education, Universitas Siliwangi, Jalan Siliwangi No. 24, Khuripan Kec. Tawang Tasikmalaya, Jawa Barat, 46115, Indonesia email: agusarifrahman@unsil.ac.id ${ }^{1}$, aangrohyana@unsil.ac.id ${ }^{2}$

\section{Info Artikel}

Sejarah Artikel:

Diterima 29 Desember 2019

Disetujui 25 Juli 2020

Dipublikasikan 29 Juli 2020

Keywords:

Riset and Developmen, Prototipe, Softball

\begin{abstract}
Abstrak
Penelitian ini bertujuan untuk mengetahui uji kelayakan pengembangan model prototipe dari salah satu latihan reaksi terhadap peningkatan kecepatan dalam lempar atas pada cabang olahraga softbal. Metode penelitian menggunakan metode penelitian Research And Development $(R \& D)$ Menurut Borg and Gall dengan langkah; potensi dan masalah, pengumpulan data, rancangan desain produk, validasi dan revisi desain serta lankah berikutnya dilakukan uji coba produk kepada kelompok kecil dan kelompok besar. Uji coba penelitian kelompok kecil dilaksanakan pada club cabang olahraga softball sebanyak 15 orang. Sedangkan hasil ujicoba kelompok besar dilakukan kepada atlet Softball kota Tasikmalaya sebanyak 30 orang. Hasil Ujicoba mendpatkan kelayakan model menunjukan nilai skor hitung (SH) 600 dan skor kriterium 720 dengan prosentase 83,33\% dengan kategori Baik/Layak. Kemudian untuk aspek penggunaan mempunyai skor 857 dan skor kriterium 960 dengan prosentase $89,27 \%$ dengan kategori Baik/Layak. Sehingga dapat disimpukan bahwa hasil dilapangan dalam penggunaan alat dapat direkomendasikan layak untuk digunaan.
\end{abstract}

\footnotetext{
Abstract

This study aims to determine the feasibility test of developing a prototype model of one of the reaction exercises to increase the speed of throwing on softball. The research method uses the Research and Development (RnD) research method according to Borg and Gall with steps; potential and problems, data collection, product design, design validation and revision and subsequent trials of product testing for small groups and large groups. Small group research trials were conducted at 15 clubs for softball sports. While the results of a large group trial were conducted on Softball athletes in the city of Tasikmalaya as many as 30 people. The trial results get the feasibility of the model showing the calculated score (SH) of 600 and the criterion score of 720 with a percentage of $83.33 \%$ with the category of Good / Eligible. Then for the aspect of use has a score of 857
} 
and 960 criterion score with a percentage of $89.27 \%$ with the category Good / Eligible. Therefore, it can be concluded that the results in the field in the use of tools can be recommended for use.

\footnotetext{
$\bowtie$ Alamat korespondensi: Universitas Siliwangi, Jalan Siliwangi No. 24, Khuripan Kec. Tawang Tasikmalaya, Jawa Barat

E-mail

: aangrohyana@unsil.ac.id
}

\section{PENDAHULUAN}

Permainan Softball merupakan cabang olahraga yang populer di Indonesia, hal ini terbukti dengan semakin banyaknya didirikan perkumpulan-perkumpulan Softball baik di kota-kota besar maupun di daerah-daerah. (Pradnyaswari \& Budisetyani, 2018) Selain bisa dijadikan olahraga prestasi, olahraga softball juga bisa dijadikan olahraga rekreasi hal ini dikarenakan mengandung unsur permainan, sehingga dari anak-anak sampai orang dewasa pun menyukai olahraga ini. Situasi dan kondisi seperti ini sangat mendukung terhadap proses pembinaan dan pengembangan cabang olahraga Softball selanjutnya dan menuju tercapainya prestasi yang optimal.

Perkembangan pembinaan prestasi dewasa ini tidak terlepas dengan Revolusi industri 4.0 akan membawa banyak perubahan dengan segala konsekuensinya, hal tersebut dipertegas (Tjandrawinata, 2016) industri akan semakin kompak dan efisien, kemajuan teknologi memungkinkan terjadinya otomatisasi hampir di semua bidang. Namun ada pula risiko yang mungkin muncul, misalnya berkurangnya Sumber Daya Manusia karena digantikan oleh mesin atau robot. Dunia saat ini memang tengah mencermati revolusi industri 4.0 ini secara seksama. Berjuta peluang ada di situ, tapi di sisi lain terdapat berjuta tantangan yang harus dihadapi. Segala kemudahan dapat di kembangkan dengan kemajuan jaman saat ini sehingga menjadi trend. Perkembangan jaman menuntun para praktisi olaharaga khususnya melakukan sebuah penelitian dipandang sebuah kebutuhan (Yusuf, 2015) Pada perkembangan Teknologi Informasi, teknologi tidak sekedar menjadi trend semata, tetapi sudah menjadi salah satu kebutuhan seperti halnya pengembangan khasanah keilmuan dalam proses pengembangan alat, model, metode latihan dan sebagainya seperti halnya pada proses latihan yang melibatkan moderenisasi berupa alat canggih dalam memaksimalkan proses latihan seperti berlatih pada cabang olahraga softball.

Untuk bisa bermain olahraga softball ini tentu tidak bisa dilakukan secara singkat namun harus melalui proses latihan serta penguasaan teknik dasar. Pentingnya penguasaan teknik dasar diungkapkan oleh (Harsono, 2018) Kesempurnaan teknik-teknik dasar dari setiap gerakan adalah penting oleh karena akan menentukan gerak keseluruhan, Oleh karena itu gerak-gerak dasar dalam setiap cabang olahaga harus dilatih dan dikuasai secara sempurna melibatkan alat bantu Prototipe yang dikembangkan peneliti.

Lemparan atas adalah lemparan yang dengan gerak ayunan lengan ke atas melewati garis horizontal. Teknik lemparan ini lebih sering digunakan dari pada teknik yang lain. (Soegiyanto, 2010) Lemparan atas memiliki kecepatan yang tinggi dan jarak yang jauh dikarenakan hampir seluruh badan sama-sama bergerak dalam kesatuan. Kesalahan fatal yang dilakukan pemain adalah melempar terlalu tinggi dari target atau sasaran. (Veroni et al., 2015) salah satu unsur melempar bola adalah 
ketepatan atau akurasi lemparan bola pada target yang dibutuhkan untuk melempar dengan baik bukan hanya tenaga yang kuat dan kecepatan tinggi namun ketepatan atau akurasi saat melempar menuju target juga sangat penting. (Faruqi, 2017) Tidak berguna jika lemparan kuat dan cepat namun lemparan tidak tepat pada target hingga tidak dapat ditangkap, justru akan merugikan untuk tim, baik kekuatan, kecepatan dan ketepatan harus ada pada saat melakukan lemparan. Unsurunsur yang penting dalam melempar bola menurut (Veroni et al., 2015) unsur utama yang perlu diperhatikan dalam melakukan gerakan melempar bola Softball antara lain : kecepatan, ketepatan, melempar dan jalannya bola serta kemudahan untuk melakukan gerakan lemparan. Sekaitan dengan pentingnya unsur lemparan dalam permainan softball juga diperlukan reaksi yang cepat dalam merespon untuk mematikan lawan, oleh sebab itu penulis dalam hal ini mengembangkan sebuah model prototipe guna membantu proses latihan lemparan terhadap reaksi atau respon pelempar untuk mematikan lawan. Tinggi rendahnya kecepatan seseorang dapat dipengaruhi dengan beberapa faktor yang diungkapkan oleh (Harsono, 2018) kecepatan tergantung dari beberapa faktor yang mempengaruhinya yaitu strength, waktu reaksi (reaction time), dan fleksibilitas. Pada permainan softball kecepatan reaksi sangatlah diperlukan apabila pemain bertahan mendapat bola hasil pukulan dari pemain menyerang untuk mematikan pemukul atau pelari yang ada di base, hal tersebut dijelaskan kembali oleh (Donald et al., 2013) bahwa waktu reaksi adalah waktu antara pemberian rangsang (stimulus) dengan gerak pertama. Pada intinya reaksi timbul apabila adanya rangsangan yang datang dan rangsangan tersebut bersifat mekanis (sentuhan atau gesekan), suara, cahaya, dingin, hangat dan panas. Berbagai artikel telah banyak membahas terkait kecepatan dan reaksi dalam permainan softball diantaranya diungkap oleh (Pranyoto, 2016) dalam penelitiannya diungkap kesenjangan yang terjadi dari kurangnya kecepatan reaksi pada sampel sehingga solusi yang ditawarkan dengan memanfaatkan media bola reaksi, oleh sebab itu untuk mewujudkan dan memksimalkan proses latihan perlu adanya media yang dikembangkan seperti Modelmodel pengembangan berupa prototype memang banyak di teliti guna menghasilkan sebuah produk untuk membantu dalam proses pengembangan keilmuan. Seperti pada beberapa penelitian pengembangan yang banyak diteliti diantaranya (Muttaqin et al., 2016) mengembangkan model latihan smash bola voli, hasil pengembangan model tersebut dibuktikan dengan hasil penelitian bahwasannya model pengembangan tersebut efektif digunakan dalam variasi latihan smash kemudian penelitian pengembangan lain yang dilakukan oleh (Soenyoto, 2014) penelitian tersebut untuk mengembangkan model alat jamur bagi atlet senam artistik putra tingkat junior dan senior dengan tujuan untuk meningkatkan keterampilan gerak pada alat kuda pelana alat prototype tersebut dibuat guna membantu proses latihan, namun demikian alat bantu untuk pelatihan teknik dalam permainan softball sangat kurang apalagi alat yang sudah dikembangkan seblumnya menjadi komersial dan mahal, oleh sebab itu pengembangan ini dirancang guna membantu proses latihan khususnya reaksi yang akan peneliti terapkan adalah latihan reaksi yang melalui rangsangan dengan sinyal lampu dan sinyal bunyi. Penelitian pengembangan yang telah dilakukan berikut adalah pengembangan bola reaksi dalam hubungan koordinasi mata tangan, hasil penelitian tersebut mengungkap bahwa media sangat berperan dalam membantu proses pembelajaran ataupun latihan seperti melatih reaksi dalam pukulan. Bola reaksi merupakan sarana pembelajaran maupun latihan dalam pendidikan jasmani, olahraga dan kesehatan, guna meningkatkan kecepatan reaksi serta koordinasi mata, tangan, dan kaki (Pranyoto, 
2016). Kondisi tersebut menjadi sebuah tantangan bagi peneliti guna menghasilkan sebuah produk pengembangan Prototipe alat bantu latihan reaksi yang menggunakan sinyal lampu dengan bunyi terhadap kecepatan dalam lempar atas pada cabang olahraga softball pada atlet cabang olahraga softball Kota Tasikmalaya.

\section{METODE PENELITIAN}

Metode penelitian ini menggunakan metode penelitian dan pengembangan atau disebut research and development ( $\mathrm{R} \& \mathrm{D})$. Educational Research and Development biasa juga disebut Research Based Development. "Educational Research and Development is a process used to develop and validate educational products" (Sugiyono, 2017). Penelitian dan Pengembangan adalah suatu proses atau langkah-langkah untuk mengembangkan suatu produk baru atau menyempurnakan produk yang telah ada. Yang dimaksud dengan produk dalam konteks ini adalah mengembangkan model prototipe untuk membantu proses latihan reaksi yang memakai sinyal lampu dengan bunyi terhadap kecepatan dalam lempar atas pada cabang olahraga softball dapat berfungsi dengan baik. Menurut Borg and Gall (Arikunto, 2017), yang dimaksud dengan model penelitian dan pengembangan adalah " $a$ process used develop and validate educational product". Adapun langkah-langkah dalam penelitian dijabarkan dengan gambar sebagai berikut:

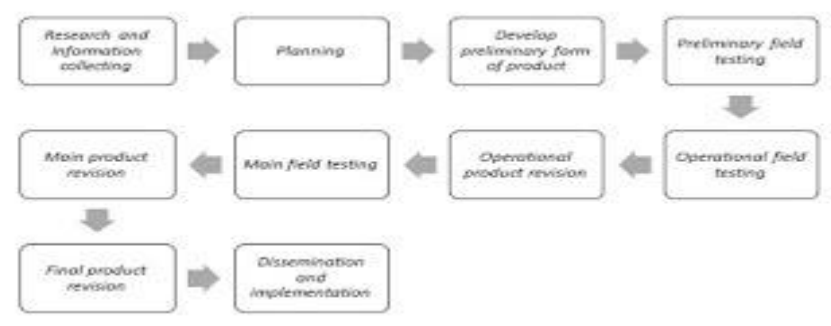

Gambar 1. Langkah penelitian Research and Development Brog and Gall

\section{HASIL DAN PEMBAHASAN}

\section{Hasil}

Hasil Penelitian dalam pelaksanaan pelakasanaan reduksi data dijabarkan dalam langkah-langkah dalam prosedur yang dikemukakan brog and gall pada hasil penelitian pengembangan model prototipe untuk membantu proses latihan reaksi yang memakai sinyal lampu dengan bunyi terhadap kecepatan dalam lempar atas pada cabang olahraga softball dapat berfungsi dengan baik dengan prosedur model sebagai berikut.

\section{a. Potensi dan masalah}

Perkembangan pembinaan prestasi dewasa ini tidak terlepas dengan Revolusi industri 4.0 akan membawa banyak perubahan dengan segala konsekuensinya, industri akan semakin kompak dan efisien. Namun ada pula risiko yang mungkin muncul, misalnya berkurangnya Sumber Daya Manusia karena digantikan oleh mesin atau robot. Dunia saat ini memang tengah mencermati revolusi industri 4.0 ini secara saksama. Berjuta peluang ada di situ, tapi di sisi lain terdapat berjuta tantangan yang harus dihadapi. Segala kemudahan dapat di kembangkan dengan kemajuan jaman saat ini seperti halnya pada proses latihan yang melibatkan moderenisasi berupa alat canggih dalam memaksimalkan proses latihan seperti halnya berlatih pada cabang olahraga softball. Dalam permaian softbal salah satu unsur yang paling penting untuk mematikan lawan salah satunya adalah lemparan yang dilakukan oleh seorang pemain kepada pemain lain yang berlari masuk ke base Sekaitan dengan pentingnya unsur lemparan dalam permainan softball juga diperlukan reaksi yang cepat dalam merespon 
untuk mematikan lawan, oleh sebab itu penulis dalam hal ini mengembangkan sebuah model prototipe guna membantu proses latihan lemparan terhadap reaksi atau respon pelempar untuk mematikan lawan dengan menggunakan indra penglihatan berupa lampu dan indra pendengaran berupa bunyi (buzze). Pemanfaatan media menjadi potensi yang bisa dikembangkan peneliti untuk menghasilkan sebuah produk berupa prototipe guna menyelesaikan persoalan tersebut.

\section{b. Pengumpulan data}

Pengumpulan data yang penulis lakukan tidak terlepas dari data yang terkumpul melalui informasi data sekunder maupun data primer, data-data yang diperlukan peneliti guna menunjang keberhasilan pengembangan model prototipe yang dikembangan oleh peneliti, data tersebut lebih terproyeksikan terkait pembuatan prototipe alat bantu latihan reaksi dengan menggunakan sinyal lampu untuk reaksi terhadap indra penglihatan dan bunyi untuk indra pendengaran.

\section{c. Rancangan Model/Desain Produk}

Rancangan model yang dikembangkan peneliti di jabarkan dalam bentuk desain rangkaian komponen alatnya sebagaimana terpaparkan dalam gambar yang telah dibuat.

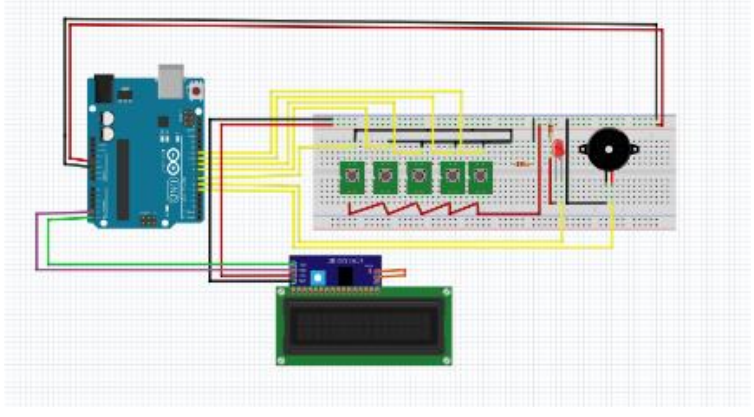

Gambar 2. Rangkaian Komponen Alat

1) Cara Kerja Pengembangan Prototipe

Pada prinsipnya model pengembangan ini dibuat dengan dua fungsi dalam membantu proses latihan reaksi yaitu yang pertama dengan menggunakan media cahaya berupa lampu dan media bunyi melalui buzzer, alat tersebut dibuat dan dirancang secara otomatis dengan durasi waktu di setting seberapa lama cahaya maupun bunyi bekerja untuk di respon oleh pelempar. Kemudian mengacu kepada prinsip desain penelitian yang penulis rancang, penulis melakukan pembuatan alat atau model prototipe tersebut dibantu oleh profesional di bidang teknik elektro, dilanjutkan dengan penilaian expert judgment (ahli/pakar) elektro perancang model terhadap indikator desain yang telah penulis susun, Penilaian atau validasi dengan expert judgment adalah untuk memeriksa prosedur pengembangan model prototipe untuk membantu proses latihan reaksi yang memakai sinyal lampu dengan bunyi terhadap kecepatan dalam lempar atas pada cabang olahraga softball dapat berfungsi dengan baik serta mengevaluasi relevansi dengan variabel yang ditentukan.

2) Algoritma Alat

Algoritma alat pengemabangan prototipe sebagai berikut :

1. Ketika tombol delay ditekan maka system akan membaca berapa lama jeda waktu per output yang akan dihasilkan.

2. Tombol delay terdiri dari 2 tombol yaitu delay (-) dan Delay (+).

3. Tombol delay (-) berfungsi memasukan input yaitu pengurangan jeda waktu 1 detik untuk satu kali tekanan tombol, dan secara otomatis akan ditampilkan oleh layar LCD Setiap kelipatan tekanan tombolnya.

4. Tombol delay (+) berfungsi memasukan input yaitu penambahan jeda waktu 1 detik 
untuk satu kali tekanan tombol, dan secara otomatis akan ditampilkan oleh layar LCD Setiap kelipatan tekanan tombolnya.

5. Selanjutnya adalah memilih output yang akan dikeluarkan oleh sistem.

6. Saat tombol LED ditekan, sistem membaca bahwa ouput yang akan dihasilkan adalah berupa nyala lampu LED sebanyak 5 kali dan dengan jeda waktu antara nyala lampu sesuai dengan lamanya waktu jeda yang telah ditetapkan, dan jeda waktu pertama akan dihitung ketika tombol sudah ditekan.
7. Sedangkan saat tombol Buzzer ditekan, sistem membaca bahwa ouput yang akan dihasilkan adalah berupa bunyi Buzzer sebanyak 5 kali dan dengan jeda waktu antara bunyi Buzzer sesuai dengan lamanya waktu jeda yang telah ditetapkan, dan jeda waktu pertama akan dihitung ketika tombol sudah ditekan.

8. Terakhir ketika tombol Reset ditekan maka jeda waktu dan mode output yang telah ditentukan akan dihapus oleh sistem dan alat kembali ke keadaan awal.

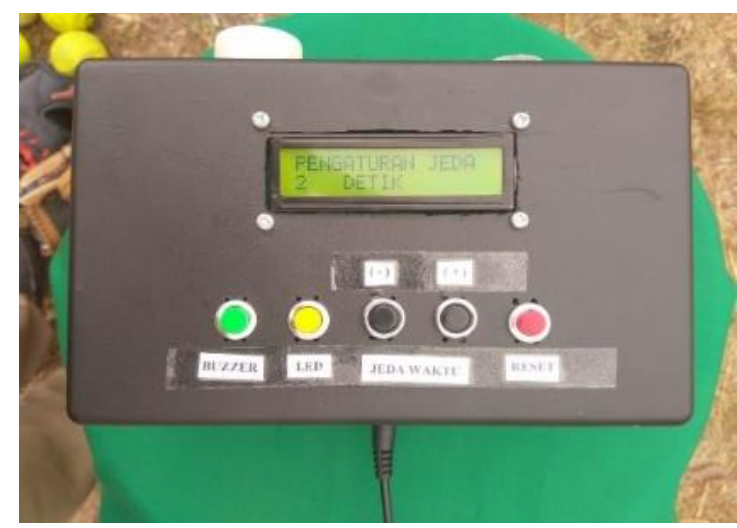

Gambar 3. Alat

\section{3) Deskripsi Alat}

Alat ini adalah sebuah prototype yang dapat membantu pelempar dalam latihan melempar bola Softball. Dengan menggunakan alat ini seorang pelempar bisa melihat seberapa cepat reaksinya melempar bola ketika ada aba-aba yang keluar dari alat ini. Disamping itu alat ini bisa digunakan sebagai media pembantu pelatih untuk melihat reaksi seorang Pelempar dalam melakukan lemparan bola. Pelatih dapat melihat reaksi Pelempar ketika diberi aba-aba berupa isyarat nyala lampu dan bunyi Buzzer lalu membandingkan waktu reaksi Pelempar yang diperoleh dari kedua aba-aba tersebut.

4) Tata Cara Penggunaan Alat

Adapun tata cara penggunaan alat prototipe sebagai berikut :

1. Pasangkan Adaftor pada stop kontak

2. Atur jeda waktu nyala LED/Buzzer yang dinginkan dengan menekan tombol : a. Delay (-) untuk menguranngi jeda waktu 1 detik

b. Delay (+) untuk menambah jeda waktu 1 detik

3. Setelah itu tekan tombol :

a. LED, untuk menyalakan LED

b. Buzzer, untuk menyalakan Buzzer

4. Ketika akan berganti mode dari LED ke Buzzer atau Buzzer ke LED, tekan tombol reset lalu ulangi langkah 2 dan 3

d. Validasi Desain

Kemudian mengacu kepada langkahlangkah dalam desain penelitian berikutnya penulis melalkukan konsultasi kepada expert judgment (ahli/pakar) pembuat alat elektro terhadap pengembangan model prototipe alat bantu latihan reaksi dengan menggunakan sinyal bunyi dan lampu yang telah disusun, Penilaian atau validasi dengan expert judgment adalah untuk memeriksa prosedur 
pengembangan model prototipe alat bantu latihan reaksi dengan menggunakan sinyal bunyi dan lampu secara sistematis serta mengevaluasi relevansi dengan variabel yang ditentukan. Hal ini dilakukan untuk mengetahui sejauh mana pengembangan model prototipe yang digunakan dalam penelitian telah mencerminkan keseluruhan aspek yang diukur. Expert judgment menggunakan satu orang ahli yakni ahli/pakar elektro.

\section{e. Revisi Desain}

Pada hasil konsultasi dengan expert judgment (ahli/pakar) pembuat alat elektro secara konsep yang penulis buat kemudian muncul revisi model pengembangan prototipe yang diantaranya berkenaan dengan daya yang digunakan jangan menggunakan baterai namun menggunakan charger, kemudian lampu yang digunakan tidak terlalu jelas dikarenakan di lapangan terangnya cahaya matahari terlalu terang shingga kapasitas lampu harus di tingkatkan dan diganti dengan LED, Boks yang digunakan dengan menggunakan akrilik, namun pakar memberi saran agar di ganti dengan menggunakan boks yang sudah jadi.

\section{f. Uji Coba Produk Kelompok Kecil}

Penelitian dilaksanakan ujicoba instrumen dalam dua tahap. Tahap pertama adalah uji coba kelompok kecil dilakukan di club sebanyak 15 orang atlet softball di Kota Tasikmalaya sebagai representatif perwakilan atlet di berbagai club secara proporsional. Pada tahap ini diujicobakan rancangan desain Model pengembangan model prototipe untuk membantu proses latihan reaksi yang memakai sinyal lampu dengan bunyi terhadap kecepatan dalam lempar atas pada cabang olahraga softball yang telah disusun. Adapun tahapantahapan kerangka model Model pengembangan prototipe untuk membantu proses latihan reaksi yang memakai sinyal lampu dengan bunyi terhadap kecepatan dalam lempar atas pada cabang olahraga softball yang diujicobakan sebagai berikut :

1. Tahap persiapan

1) Mengumpulkan responden dilapangan

2) Menyiapkan dan mensetting alat yang dibuat

3) Menyiapkan perlengkapan pendukung kegiatan di lapangan

2. Tahap pelaksanaan

1) Mendata dan melakukan pemanasan kepada responden

2) Melakukan ujicoba dengan prosedur yang telah disampaikan secara bergiliran

3. Tahap akhir

1) Memberikan penjelasan kembali hasil pelaksanaan ujicoba alat

2) Memberikan evaluasi menyeluruh dari kinerja alat yang dibuat

3) Penyebaran angket

Intrument untuk mereduksi data dalam pengujian model pengembangan prototipe ini dengann menggunakan angket atau kuisioner terbuka kepada responden pada kelompok kecil tersebut, sehingga muncul kekurangankekurangan yang muncul pada pengembangan model prototipe yang dikembangkan. Instrumen yang dirancang oleh penulis melalui uji validitas oleh ahli. Teknik analisa data yang dilakukan pada penelitian ini adalah teknik analisa kuantitatif yang bersifat penilaian menggunakan angka. Persentase dimaksudkan untuk mengetahui status sesuatu yang dipersentasekan dan disajikan tetap berupa persentase.

Hasil perhitungan data selanjutnya dibuat dalam bentuk persentase dengan dikalikan $100 \%$. Setelah diperoleh persentase dengan rumus tersebut, selanjutnya kelayakan dalam pengembangan model prototipe untuk membantu proses latihan reaksi yang memakai sinyal lampu dengan bunyi terhadap kecepatan dalam lempar atas pada cabang olahraga softball digolongkan dalam empat kategori kelayakan dengan menggunakan Skala sebagai berikut: 
Tabel 1 Kategori Presentase Kelayakan

\begin{tabular}{lll}
\hline No & Skor dalam persentase & Kategori Kelayakan \\
\hline 1 & $<40 \%$ & Tidak Baik/Tidak Layak \\
2 & $40 \%-55 \%$ & Kurang Baik/Kurang Layak \\
3 & $56 \%-75 \%$ & Cukup Baik/Cukup Layak \\
4 & $76 \%-100 \%$ & Baik/Layak \\
\hline
\end{tabular}

Angket yang digunakan dalam peneitian ini adalah angket penilaian atau tanggapan dengan bentuk jawaban dan keterangan penilaian 1: Sangat tidak setuju/sangat tidak layak, 2: Tidak sesuai/tidak layak, 3: Sesuai/layak, 4 : Sangat sesuai/sangat layak.

Setelah ujicoba kelompok kecil dilaksanakan kemudian peneliti mengumpulkan informasi mengenai hasil pelaksanaan uji coba model prototipe untuk membantu proses latihan reaksi yang memakai sinyal lampu dengan bunyi terhadap kecepatan dalam lempar atas pada cabang olahraga softball tersebut dengan menggunakan angket atau kuisioner terbuka kepada responden pada kelompok kecil tersebut sehingga muncul kekurangan-kekurangan yang muncul pada pengembangan model prototipe tersebut. Dari data perhitungan dan kategori kelayakan model menunjukan bahwa nilai skor hitung (SH) fisik mempunyai skor 276 dan skor kriterium 450 sehingga didapat nilai prosentase untuk aspek fisik mendapat $61,33 \%$ dengan kategori cukup layak setelah dikonfersi pada tabel kelayakan. Kemudian untuk aspek penggunaan mempunyai skor 431 dan skor kriterium 600 sehingga didapat nilai prosentase untuk aspek penggunaan mendapat 71,83\% dengan kategori cukup layak setelah dikonfersi pada tabel kelayakan. Dari skor perhitungan di atas dapat disimpukan dari kedua aspek tersebut mendapatkan skor kelayakan $66,58 \%$ dengan kategori cukup layak, artinya nilai tersebut layak untuk di uji cobakan kembali kepada tahap berikutnya yaitu uji kelompok besar.

Adapun hasil saran responden yang penulis sediakan pada kolom komentar saat penyebaran angket dilapangan didapatkan informasi mengenai kualitas pengembangan model prototype untuk membantu proses latihan aksi reaksi yang memakai sinyal lampu dengan bunyi terhadap kecepatan dalam lemparan atas pada cabang olahraga softball dan pada dasarnya semua responden setelah menggunakan alat ini mereka merasa sangat terbantu dengan adanya alat tersebut, diyakini juga alat ini sangat menarik dan dapat melatih aksi dan reaksi khususnya pada lemparan softball. Adapun rata rata saran yang penulis simpulkan dari hasil data dilapangan yang diberikan oleh responden terhadap alat ini pada aspek fisik dan aspek penggunaan yaitu dimulai dari segmen diameter lampu yang kecil agar dapat diganti dengan lampu yang lebih besar dan penggunaan cahaya lampu dapat diganti dengan warna hijau,kuning atau merah dan dari segi penempatan lampu agar dapat dipisahkan dengan alatnya dan diletakkan didepan pelempar supaya dapat terlihat langsung pada saat melempar. Selanjutnya dari segmen power suplay arus listrik diharapkan dapat mengunakan powerbank supaya alat tersebut dapat dibawa agar praktis dan memakai remote control. Responden pun ada yang memberikan saran bahwa Suara buzzer (bunyi) agar dapat volumenya ditingkatkan supaya terdengar jelas.

\section{g. Ujicoba Produk Kelompok Besar \\ Pada tahapan penelitian ini setelah} dilakukan uji coba kelompok kecil kemudian diujicobakan kepada kelompok besar sebanyak 4 club softball Kota Tasikmalaya diambil sebanyak 30 orang atlet softball. Setelah tahapan revisi ahli/pakar yang disempurnakan pada hasil ujicoba kelompok kecil. Adapun tahapan-tahapan kerangka model Model pengembangan prototipe untuk membantu proses latihan reaksi yang memakai sinyal 
lampu dengan bunyi terhadap kecepatan dalam lempar atas pada cabang olahraga softball yang diujicobakan sama seperti halnya uji coba kelompok kecil yang diantaranya sebagai berikut :

1. Tahap persiapan

1) Mengumpulkan responden dilapangan

2) Menyiapkan dan mensetting alat yang dibuat

3) Menyiapkan perlengkapan pendukung kegiatan di lapangan

2. Tahap pelaksanaan

1) Mendata dan melakukan pemanasan kepada responden

2) Melakukan ujicoba dengan prosedur yang telah disampaikan secara bergiliran

3. Tahap akhir

1) Memberikan penjelasan kembali hasil pelaksanaan ujicoba alat

2) Memberikan evaluasi menyeluruh dari kinerja alat yang dibuat

3) Penyebaran angket

Setelah ujicoba kelompok besar dilaksanakan kemudian peneliti mengumpulkan informasi mengenai hasil pelaksanaan uji coba model prototipe untuk membantu proses latihan reaksi yang memakai sinyal lampu dengan bunyi terhadap kecepatan dalam lempar atas pada cabang olahraga softball tersebut dengan menggunakan angket atau kuisioner terbuka kepada responden pada kelompok kecil tersebut sehingga muncul kekurangan-kekurangan yang muncul pada pengembangan model prototipe tersebut.

Dari data perhitungan dan kategori kelayakan model Pada uji coba kelompok besar menunjukan bahwa nilai skor hitung (SH) fisik mempunyai skor hitung 600 dan skor kriterium 720 sehingga didapat nilai prosentase untuk aspek fisik mendapat $83,33 \%$ dengan kategori Baik/Layak setelah dikonfersi pada tabel kelayakan. Kemudian untuk aspek penggunaan mempunyai skor 857 dan skor kriterium 960 sehingga didapat nilai prosentase untuk aspek penggunaan mendapat 89,27\% dengan kategori Baik/Layak setelah dikonfersi pada tabel kelayakan. Dari skor perhitungan di atas dapat disimpukan dari kedua aspek tersebut mendapatkan skor kelayakan $86,30 \%$ dengan kategori Baik/Layak, artinya nilai tersebut alat yang dikembangkan peneliti dinyatakan layak untuk digunakan, namun kelayakan penggunaan alat tersebut perlu di uji efektifitasnya pada penelitian yang penulis rencanakan pada tahun berikutnya.

Adapun hasil saran responden pada kelompok besar yang penulis sediakan pada kolom komentar pada saat penyebaran angket dilapangan didapatkan informasi mengenai kualitas pengembangan model prototype untuk membantu proses latihan aksi reaksi yang memakai sinyal lampu dengan bunyi terhadap kecepatan dalam lemparan atas pada cabang olahraga softball dan pada dasarnya semua responden pada kelompok besar setelah melakukan pengujian alat prototype responden merasa penggunaan alat tersebut sangat membantu dalam pelaksanaan pelatihan aksi dan reaksi pada kecepatan lemparan softball. Adapun rata rata saran yang penulis simpulkan dari hasil data dilapangan yang diberikan oleh responden terhadap alat ini pada aspek fisik dan aspek penggunaan yaitu alat yang digunakan terlalu kecil untuk dillihat dan penggunaan atau fungsi alat tersebut sudah sangat baik. Selebihnya resonden memberikan respon secara positif kepada alat prototype tersebut.

\section{h. Diseminasi model prototype}

Desiminasi pada penelitian ini belum bisa dijabarkan dikarenakan ujicoba lapangan (Uji efektivitas) belum dilakukan.

\section{Pembahasan}

Dalam sebuah penelitian sudah barang tentu harus mempunyai kebaharuan dan kebermaknaan dalam hasil luaran penelitiannya, terutama dalam pelaksanaan kegiatan dalam penelitian pengembangan ini mempunyai luaran produk model prototype untuk membantu proses latihan aksi reaksi 
yang memakai sinyal lampu dan bunyi terhadap kecepatan dalam lemparan atas pada cabang olahraga softball, penggunaan media berupa prototype dalam penelitian ini sangat penting, pada pelaksanaannya proses latihan lebih efektif, hal tersebut diperkuat oleh (Jatmika, 2005) media dipergunakan untuk mempermudah dalam penyampaian materi serta berperan besar dalam mempermudah proses pembelajaran/latihan. Hal serupa diungkap pada hasil penelitian lain (Septinadi, 2018) bahwasannya media merupakan salah satu bagian strategi dalam melaksanakan latihan guna memperoleh hasil secara efektif. Pada prinsipnya pembuatan prototype yang penulis rancang bertujuan untuk memaksimalkan dan mempermudah proses latihan reaksi responden. Pada dasarnya semua responden yang terlibat dalam penelitian ini setelah melakukan pengujian alat prototype memberikan kesimpulan bahwa responden merasa penggunaan alat tersebut sangat membantu dalam pelaksanaan pelatihan aksi dan reaksi pada kecepatan lemparan softball. Kecepatan dan reaksi menjadi focus penelitian dalam pengembangan prototipe ini dikarenakan pada permainan softball kecepatan reaksi sangatlah diperlukan apabila pemain bertahan mendapat bola hasil pukulan dari pemain menyerang untuk mematikan pemukul atau pelari yang ada di base.

Tinggi rendahnya kecepatan seseorang dapat dipengaruhi dengan beberapa faktor yang diungkapkan (Aras et al., 2017) kecepatan tergantung dari beberapa faktor yang mempengaruhinya yaitu strength, waktu reaksi (reaction time), dan fleksibilitas. (Lestari, 2019) Kecepatan reaksi terhadap keberhasilan memukul bola pada cabang olahrga softball merupakan salah satu variabel penentu. Seperti halnya penelitian lain terkait senam yang dilakukan (Soenyoto, 2014) alat prototype yang dikembangkan sebagai sarana latihan bagi atlet senam artistik putra tingkat pemula, junior dan senior; serta sebagai sarana lomba bagi atlet senam artistik putra khusus tingkat pemula memberi dampak positif. Adapun hasil dilapangan dam penelitian ini rata rata saran yang penulis simpulkan dari hasil data hasil reduksi yang diberikan oleh responden terhadap alat ini pada aspek fisik dan aspek penggunaan yaitu alat yang digunakan terlalu kecil untuk dillihat dan penggunaan atau fungsi alat tersebut sudah sangat baik. Selebihnya responden memberikan respon secara positif kepada alat prototype tersebut. Hal serupa pernah diteliti dalam artikel ilmiah terkait input luaran produk pengembangan terhadap hasil belajar bahwasannya (Juniar et al., 2019) secara umum persepsi mahasiswa memberikan respons positif dan merasakan hal yang berbeda setelah mendapatkan perlakuan menggunakan model/produk yang dikembangkan. Memperkuat hasil penelitian serupa (Malik et al., 2013) mengungkapkan bahwa produk hasil pengembangan berupa ular tangga olahraga yang diimplementasikan dengan sistem laithan sirkuit terbukti memberikan dampak positif terhadap hasil pembelajaran.

Hal lain terungkap dalam temuan penelitian pengembangan alat ini bukan hanya keterampilan dalam memukul dan reaksi yang cepat namun demikian beberapa faktor pendukung penentu keberhasilan juga tak lepas dari aspek tingkat intelegensi dan emosional atau IQ (Intelligent Quotient) dan EQ (Emotional Quotinal) atlet softball itu sendiri, peniulis memperhatikan atlet pada saat memukul bola, pemain tersebut apakah mampu untuk berfikir dan merasakan gejala emosional secara tepat ketika hendak melakukan gerakan pukulan dari reaksi cahaya dan bunyi yang dihasilkan alat pengembangan yang dibuat oleh peneliti. Hal tersebut sejalan dengan penelitian yang dilakukan fazari dalam artikelnya menjelaskan bahwa IQ (Intelligence Qoutient) dan EQ (Emotional Quotient) termasuk dalam input yang berperan penting dalam menentukan tugas gerak. Dengan demikian, IQ (Intelligence Qoutient) dan EQ 
(Emotional Quotient) dapat menentukan baik atau buruknya keterampilan bermain seorang atlet. (Fazari et al., 2017).

\section{SIMPULAN}

Olahraga softball merupakan salah satu cabang olahraga yang banyak diminati oleh masyarakat dipandang olahraga ini merupakan olahraga prestasi dan dipertandingkan di berbagai level kejuaraan, namun demikian masyarakat ataupun atlet dalam pembinaannya rata-rata di setiap daerah kurang maksimal dalam menjalankan proses latihannya dikarenakan proses latihan yang terbilang monoton. Lemparan atas dalam teknik dasar softball menjadi perhatian khusus peneliti dikarenakan teknik dasar tersebut menjadi bagian penting untuk mematikan lawan, namun demikian teknik lemparan atas tersebut memerlukan aksi dan reaksi yang sangat cepat untuk merespon lemparan bola dalam mematikan langkah lawan ke dalam best. Para pemain rata-rata kurang mempunyai respon atas reaksi yang diterimanya, oleh sebab itu penulis mengembangkan suatu prototype guna melatih respon atau reaksi terhadap bunyi dan cahaya. Alat bantu berupa prototype dalam melatih Reaksi sendiri sangat penting dalam permainan softball dalam upaya memberikan metode baru dalam melatih reaksi. Pengembangan alat bantu sangat diperlukan selain mempunyai nilai materil yang terjangkau juga mempunyai nilai guna dalam variasi latihan tersebut.

\section{UCAPAN TERIMA KASIH}

Dalam proses penyusunan penelitian ini penulis banyak sekali menghadapi rintangan, namun dalam pelaksanaannya penulis tidak terlepas dari bantuan dari berbagai pihak yang telah memberikan motivasi, masukan bimbingan, serta bantuan materil yang lembaga berikan demi terlaksanannya penelitian ini terkhusus untuk LP2MP-PMP Universitas Siliwangi serta Fakultas keguruan dan ilmu pendidikan beserta Jurusan pendidikan Jasmani, tak lupa untuk rsponden atlet Softball Kota Tasikmalaya beserta club yang aktif membantu mulai dari awal sampai dengan selesainya penelitian ini. Untuk itu penulis mengucapkan terimakasih kepada semua pihak yang telah disbutkan dan berbagai pihak yang tidak bisa disebutkan satu persatu. Semoga amal baiknya menjadi amal ibadah amin.

\section{Daftar Pustaka}

Aras, D., Arsyad, A., \& Hasbiah, N. (2017). Hubungan antara Fleksibilitas dan Kekuatan Otot Lengan dengan Kecepatan Renang. Media Kesehatan Masyarakat Indonesia Universitas Hasanuddin, 13(4), 380-385.

Arikunto, S. (2017). Dasar-Dasar Evaluasi Pendidikan (2nd ed.). Jakarta: PT. Bumi Aksara.

Donald A. Chu, P., \& Gregory D. Myer, P. (2013). Donald A. Chu, PhD Gregory D. Myer, $P h D$.

Faruqi, C. A. (2017). Pengembangan Media Latihan Batting Tee Sederhana Dalam Permainan Softball. Unimed.

Fazari, Muhamad, Imas Damayanti, N. I. R. (2017). Hubungan Kecerdasan Inteleqtual ( IQ ) dan Keterampilan Bermain Dalam Cabang Olahraga Bulu Tangkis, 02(01), 33-37. https://doi.org/https://doi.org/10.17509/jti kor.v4i2.19124

Harsono. (2018). Kepelatihan Olahraga, Teori dan Metodologi. Jakarta.

Jatmika, H. M. (2005). Pemanfaatan Media Visual dalam Menunjang Pembelajaran Pendidikan Jasmani di Sekolah Dasar. Jurnal Pendidikan Jasmani Indonesia, 3(1), 89-99. 
Juniar, D. T., Rohyana, A., \& Rahmat, A. A. (2019). Pengembangan Model Pembelajaran Diskusi Kelompok Dalam Meningkat Pemahaman dan Aktivitas Belajar Mahasiswa. JUARA: Jurnal Olahraga, $\quad 4(1), \quad 15$. https://doi.org/10.33222/juara.v4i1.381

Lestari, A. T. (2019). Studi Kausal Dengan Analisis Jalur (Path Analysis) Pengaruh Kekuatan, Kelentukan, Kecepatan Reaksi, dan Efikasi Diri Terhadap Keberhasilan Memukul Pada Cabang Olahraga Softball.

Malik, A. A., Priyono, B., \& Qoriah, A. (2013). Ular Tangga Olahraga. Media Permainan Edukatif Untuk Olahraga Dengan Menggunakan Sistem Sirkuit Training Bagi Siswa Kelas X SMA Negeri Ajibarang Tahun, 630-636.

Muttaqin, I., Winarno, M. E., \& Kurniawan, A. (2016). Pengembangan model latihan smash bolavoli pada kegiatan ekstrakurikuler di smpn 12 malang. Jurnal Pendidikan Jasmani, 26(2).

Pradnyaswari, A. A. A., \& Budisetyani, I. G. A. P. W. (2018). Hubungan kecerdasan emosional dengan kecemasan bertanding pada atlet softball remaja putri di bali. Jurnal Psikologi Udayana, 5(1), 218225.

Pranyoto, fajar styo. (2016). Pengembangan Bola Reaksi Sebagai Sarana Pembelajaran Koordinasi Mata Tangan Dan Kaki Dalam Pendidikan Jasmani. Pendidikan Jasmani Kesehatan, V No.8, $1-6$.

Septinadi, B. (2018). Peningkatan Kecepatan Reaksi, Antisipasi, Dan Koordinasi
Berbasis Modifikasi Sensor, Wifi Dengan Aplikasi Android Pada Olahraga Tenis Lapang. Universitas Pendidikan Indonesia.

Soegiyanto, K. S. (2010). Pengembangan Alat Ukur Keterampilan Dasar Bermain Softball. Cakrawala Pendidikan, 3, 280293.

Soenyoto, T. (2014). Pengembangan Prototipe Alat Jamur Cabang Olahraga Senam Artistik Putra Di Provinsi Jawa Tengah. Journal of Physical Education, Health and Sport, 1(1), 19-24. https://doi.org/10.1016/j.ejogrb.2012.06. 022

Sugiyono. (2017). Metode Penelitian dan Pengembangan; Research and Development (3rd ed.). Bandung: Alfabeta.

Tjandrawinata, R. (2016). Industri 4.0: revolusi industri abad ini dan pengaruhnya pada bidang kesehatan dan bioteknologi, (February). https://doi.org/10.5281/zenodo.49404

Veroni, K., Brazier, R., Kathy, J., Veroni, K. J., \& Brazier, R. (2015). Caching Fastpitch Softball Successfully Second Edition Library of Congress Catalogingin-Publication Data.

Yusuf, E. M. (2015). Pengembangan Prototipe Sistem Informasi Geografis Fasilitas Olahraga Berbasis Mobile (Studi Kasus Fasilitas Olahraga Di Kecamatan Purwakarta) Program Studi Teknik Informatika Sekolah Tinggi Teknologi Wastukancana Jalan Raya Cikopak Sadang No 54 Purwakar, 1(1), 57-68. 